\title{
Silk Mills in the Early Modern Italy
}

\author{
Stefano Comino ${ }^{1}$, Alessandro Gasparetto ${ }^{2}$ \\ ${ }^{1}$ Department of Economics and Statistics, University of Udine, Udine, Italy \\ ${ }^{2}$ Polytechnic Department of Engineering and Architecture, University of Udine, Udine, Italy \\ Email: stefano.comino@uniud.it, alessandro.gasparetto@uniud.it
}

How to cite this paper: Comino, S., \& Gasparetto, A. (2020). Silk Mills in the Early Modern Italy. Advances in Historical Studies, 9, 284-294.

https://doi.org/10.4236/ahs.2020.95022

Received: October 30, 2020

Accepted: December 5, 2020

Published: December 8, 2020

Copyright $\odot 2020$ by author(s) and Scientific Research Publishing Inc. This work is licensed under the Creative Commons Attribution International License (CC BY 4.0).

http://creativecommons.org/licenses/by/4.0/

\begin{abstract}
In early modern times, Italian silk fabrics and threads dominated European markets. One of the drivers of the success of Italian artisans was the silk mills, able to carry out some crucial phases of silk processing. Particular importance had the mill developed by Bolognese artisans, a fully mechanized mill which is considered an early example of factory system. In this paper, after presenting a brief historical overview of the silk sector in the early modern Italy, we provide a technical description of the working principles of two families of silk mills: the mulino da seta alla bolognese (Bolognese silk mill) and the $m u$ lino da seta alla milanese o alla genovese (Milanese or Genoese silk mill).
\end{abstract}

\section{Keywords}

Silk, Silk Mill, Factory System, Silk Spinning

\section{Introduction}

In the introduction to his book on the silk sector in the pre-industrial Italy, Carlo Poni describes the silk spinning factory that John Lombe installed in 1717 in Derby-England, on the Derwent river (Poni, 2009). The building employed large cylindrical machines powered by hydraulic wheels and able to twist hundreds of silk threads at the same time. Lombe and his brother were able to collect huge amounts of profits thanks to their factory and their heirs received 14-thousand pounds from the English Parliament as a reward for their merits and for agreeing not to enforce the patent protecting the hydraulic silk mill technology. But where did this marvelous technology come from? Apparently, during his visit to Italy, Lombe learned the details of the hydraulic silk mill technology and then he used it to build his factory in England. The origins of the technology are to be found in Bologna around the mid of the XIV century. At that time the artisans of the city started using hydraulic mills for the spinning of silk; further improve- 
ments of the technology led to the development of what is known as the mulino da seta alla bolognese (Bolognese silk mill), a fully mechanized system used to carry out different phases of silk processing. The technology conceived in Bologna required little intervention from the workers and can be considered an early example of factory system (Berveglieri \& Poni, 2000). Remarkably, this automized system was in place a couple of centuries before the cotton mills that characterized the industrial revolution.

Mills were used to carry out some important phases of silk processing. Primacy in the silk mill technology played a crucial role in the success of Italian artisans whose silk fabrics largely dominated European markets until the XVII century.

The rest of paper is organized as follows. In Section 2, we provide a brief historical overview of the silk sector in the early modern Italy, and in Bologna in particular. In Section 3, we describe the structure and working principles of the Bolognese silk mill and of the Milanese silk mill; this latter was a mill driven by human rather than hydraulic power. We devote the final section to the conclusions.

\section{The Silk Industry in the Early Modern Italy}

Silk production has a long and intriguing history. The breeding of Bombyx mo$r i$-the silkworm that in the course of a few weeks produces a long and uninterrupted strand of raw silk-and the use of its cocoons to obtain yarns and fabrics originated in China a few thousand years before Christ. Silk production spread to the West in the mid of the VI century after Christ (Crippa, 2000). According to a legend, some monks, following the orders of the Roman Emperor Giustiniano, stole a few silkworm eggs, hid them in the hollow of some reeds and brought them to Byzantium. In Italy the production of silk fabrics started probably between the VIII and IX centuries in the South of the peninsula on the initiative of Arab or Byzantine immigrants (Crippa, 2000).

A central role in the development of the Italian silk sector was played by Lucca. Thanks to the techniques brought by immigrant craftmen-probably Jewish or Greek-the city became a prominent center for the production of silk fabrics in the XII century. From Lucca, in the XIV century, following a series of political upheavals, the emigration of numerous families of artisans spread silk production in other Italian cities, Venice, Bologna, Florence, Genoa and then in the rest of the peninsula. From this period onwards and until the XVII century, European markets were dominated by Italian silk fabrics and threads (Molà, 2000). While the available quantitative evidence does not allow a thorough analysis, a rough idea of the importance of the Italian silk sector can be obtained by looking at the number of looms. According to the estimates presented in Battistini (2000), at the beginning of the XVI century, about 14-thousand silk looms were in use in Italy and they represented between 70 and 75 percent of the looms existing in the whole Europe at the time. This means that about three out of four of the looms that were producing silk fabrics in Europe were Italian. Lucca (2500 looms), 
Venice (2000 looms), Bologna (1500 looms) and Genoa and Eastern Liguria (5000 looms) were the most important Italian centers.

Initially, Italian workshops employed raw silk imported from abroad. Things changed during Renaissance. The industry progressively increased the use of raw silk produced locally by peasant families for whom the breeding of silkworms became a primary source of income (Molà, 2000). The increased importance of silkworms breeding is also witnessed by a change in the landscape of Italian territories with a marked growth in the cultivation of mulberry trees, whose leaves are the only source of nourishment for silkworms. The following stages of production of silk fabrics—-spinning, twisting, weaving, dying-were carried out in cities under the direction of artisans' guilds that ensured control over the quality of products and significant monetary rewards for their masters and workers. Hence, the different stages of silk production were characterized by a clear geographical division of labor with the countryside involved in producing and supplying raw silk while more specialized and lucrative operations were carried out within cities.

\subsection{The Twisting of Raw Silk}

The silk threads produced by worms and obtained by dissolving their cocoons in boiling water is not apt to be put in use directly; at least, not to weave fabrics of high quality. Silk threads need to be twisted in order to make them robust and elastic enough to resist the stress on the loom (Molà, 2000). In the XII and XIII centuries twisting was performed manually with the use of spinning wheels. With this technique, only one thread at time could be processed, a fact that slowed down operations considerably. Also the quality of the yarns twisted with the spinning wheel was not homogeneous as the operations of rotation of the spindle and of collection of twisted yarns were not mechanically coordinated (Crippa, 2000). Much progress was possible thanks to the mechanical silk mill employed for the first time in Italy in Lucca in the XIII century. With this new technology several silk threads could be twisted simultaneously, and the quality of the resulting yarns was perfectly homogeneous. Different types of mills were employed. Initially, they were operated by a man who rotated the central axis of the mill manually. Later on, the increase in the size of mills required the use of more powerful energy sources, and hydraulically driven mills became more and more popular (Crippa, 2000). Bologna was the city where hydraulic silk mills started being used massively.

\subsection{Bologna and the Bolognese Silk Mill}

The technique for twisting raw silk using the energy produced by a water wheel was first employed in Bologna around the mid of the XIV century. At that time, a Lucchese merchant-Bolognino di Borghesano-received a license that granted him the possibility to build a hydraulic silk mill (Berveglieri \& Poni, 2000). Thanks to further technological improvements to these early machineries, a fully me- 
chanized mill-then known as the mulino da seta alla bolognese (Bolognese silk mill) - was developed. This new type of mill was able to carry out different phases of silk processing — spooling, spinning, coupling and twisting — and required minor interventions from the labor force. Workers only needed to feed the mill with raw silk, knot the threads when they broke and collect the skeins of twisted yarns. As such, according to Berveglieri \& Poni (2000), the Bolognese silk mill can be considered an early example of "factory system". Remarkably, this new machinery was in place a couple of centuries before the cotton mills that characterized the industrial revolution in England.

Table 1 shows the number of hydraulic mills active in Bologna from the late XIV century to the end of the XVIII century. While the number of cereal mills was remarkably stable, that of silk mills showed a dramatic increase until the end of the XVII century: from a handful of mills in 1393 to 353 mills reported in 1683.

The success and diffusion of silk mills in Bologna was certainly favored by a specific characteristic of the city. Bologna, beginning from the second half of the XII century, had developed a pervasive water network of about one hundred limited-capacity underground conduits (called chiaviche) able to reach different parts of the city. The chiaviche were able to produce only limited power which, however, proved to be perfectly suited for the case of silk. As a matter of fact, silk mills were able to operate on a very limited supply of energy. According to the estimates reported in Berveglieri \& Poni (2000) the energy required to operate silk mills was between one third and one fourth that needed by cereal mills.

Thanks to the effectiveness of its mills, Bologna became one of the leading European centers for the production of silk yarns and veils. Between the XV and the XVIII centuries, Bolognese artisans were internationally renowned for the high quality of their warp thread-the so-called orsoglio (organzine). Organzines from Bologna were exported all over Europe and were employed for the realization of the finest fabrics. For a long period of time, the silk sector was the most important activity in the city employing about one out of three inhabitants living in Bologna (Guenzi \& Poni, 1989).

\subsection{The Silk Mill Technology: A Precious Secret}

Bologna considered the silk mill technology as a very precious secret to be jealously guarded. Bolognese artisans suspected of having revealed to competing

Table 1. Hydraulic wheels in Bologna.

\begin{tabular}{ccccccc}
\hline & 1393 & 1653 & 1683 & 1705 & 1747 & 1785 \\
\hline Silk mills & 16 & 260 & 353 & 247 & 180 & 123 \\
Cereal mills & N.A. & 30 & 30 & 30 & 30 & 30 \\
Other plants & 21 & 20 & 20 & 30 & 46 & 51 \\
\hline
\end{tabular}

Source: Guenzi \& Poli (1989). 
cities key information regarding the technology were severely punished. Poni (1972) and Molà (2000) report two cases of artisans sentenced to death for this reason. Both cases contributed to the introduction of the Bolognese silk mill technology in the Republic of Venice. The first case is that of Ugolino Menzani, a Bolognese spinner accused of having introduced the technology in the nearby city of Modena. Although, in his defense, he argued that hydraulic silk mills were already employed in Modena before he moved to the city, Menzani was charged with high treason and sentenced to death in absentia by the Court of Bologna in 1601. A few years later, in 1604, an artisan from Modena, Ottavio Malpigli, filed a patent application to the Venetian Senate for a hydraulic silk mill, thus introducing the technology in Venice. The case reported by Molà (2000) is that of the artisan Benedetto Fontana. Fontana moved from Bologna to the Venetian mainland where he built a hydraulic mill at the end of the XVI century, few years before Malpigli's patent application. According to Molà (2000), also Fontana was condemned to death in Bologna. The Venetian Republic and the city of Modena are not the only places where the Bolognese silk mill diffused. The technology made inroads in other parts of the north of Italy, especially in Lombardy and Piedmont (Berveglieri \& Poni, 2000). Remarkably, patents for the realization of mulini alla bolognese were obtained also beyond the Italian territory. Johann Joachin Becher obtain a patent in Amsterdam in 1678 while John Lombe was awarded a 15-year patent in London in 1718 (Berveglieri \& Poni, 2000).

\section{The Mills Employed in the Silk Factory}

As already suggested above, the effectiveness of the silk mill technology originally employed in Bologna was one of the drivers for the impressive development of the silk industry in Northern Italy in early modern times. In this section, we will perform an accurate analysis of the structure and working principles of silk mills. In order to do so, we referred to some historical documents of that age, as well as to more recent books, such as the work by Poni (2009), who found and analyzed several drawings and other documents concerning silk mills.

In order to better understand the working principles of a silk mill, we summarize here the four phases of the silk processing:

1) Incannatura (spooling). The raw silk, brought to the mill in skeins, is disentangled and then loaded into rocchetti (spools) or into naspi (reels), which are then placed in the upper part of the mill;

2) Filatura (spinning). The spools (or the reels) are put into rotation and any silk thread is strongly twisted to the right, and then wrapped around another spool (or reel);

3) Binatura (coupling). The second set of spools (or reels) is put into rotation, and each silk thread is coupled to another, coming from a different spool (or reel). Any pair of threads is then wrapped around another spool (or reel).

4) Torcitura (twisting). Any pair of threads is slightly twisted to the left, and is wound around a final reel, so as to make a skein of worked silk. 
From the available drawings and documents, two basic typologies of silk mills can be identified, namely:

- the mulino da seta alla milanese o alla genovese (Milanese or Genoese silk mill)

- the mulino da seta alla bolognese (Bolognese silk mill).

The differences between these two types of mills can be inferred both from the drawings and from the descriptions of the way they worked. For instance, a very peculiar source, cited by Poni (2009), is the diary of a journey to Italy, written by an English silk tradesman of the XVII century. In this diary, written in a very curious English full of Italian words, the tradesman accurately describes the differences between the two types of mills. Namely, the Bolognese silk mill differs from the Milanese type for three fundamental features:

1) It is driven by hydraulic power, while the Milanese mill is driven by human power;

2) It is provided with tavelle, i.e. mechanical winders that allow to automatically perform the spooling operation, while such operation has to be done manually in the Milanese mill;

3) It is provided with spools, while the Milanese mill has reels.

From the above, it is clear that the mulino da seta alla bolognese was more advanced, from a technological point of view, with respect to the Milanese silk mill.

This led to some important consequences:

a) the quality of the worked silk obtained from the Bolognese silk mill was higher than that produced by the Milanese mill. This was due to the fact that the spools could give the thread a larger twist angle than the reels; moreover, the motion of the Bolognese mill, given by the rotation of the water wheel, was smoother and more regular. This greatly affected the quality of the product, because the resulting silk thread was more lucent and uniform;

b) the Bolognese silk mill allowed to automatize all the silk processing operations, with the exception of the coupling, that had to be done manually. This allowed the silk factories, which employed the Bolognese mill, to automatize an important phase of the production process, and to reduce the costs and the amount of labor required in the factory.

It is interesting to analyze the two types of silk mills from a technical point of view, starting from the drawings that can be found in ancient books and documents, and reported in the book by Poni (2009).

\subsection{The Bolognese Silk Mill}

An admirable description of the Bolognese silk mill can be found in the ancient book by Zonca (1607). In Figure 1 (taken from the Encyclopédie), the two parts of the mill (the internal and the external), are shown separately, although they are set concentrically around a common vertical axis. In Figure 2 the ghirlanda ("garland"), i.e. the internal part of the mill is depicted in detail. Figure 2 also shows the kinematic chain, which transmits the power from the water wheel to the mill. 


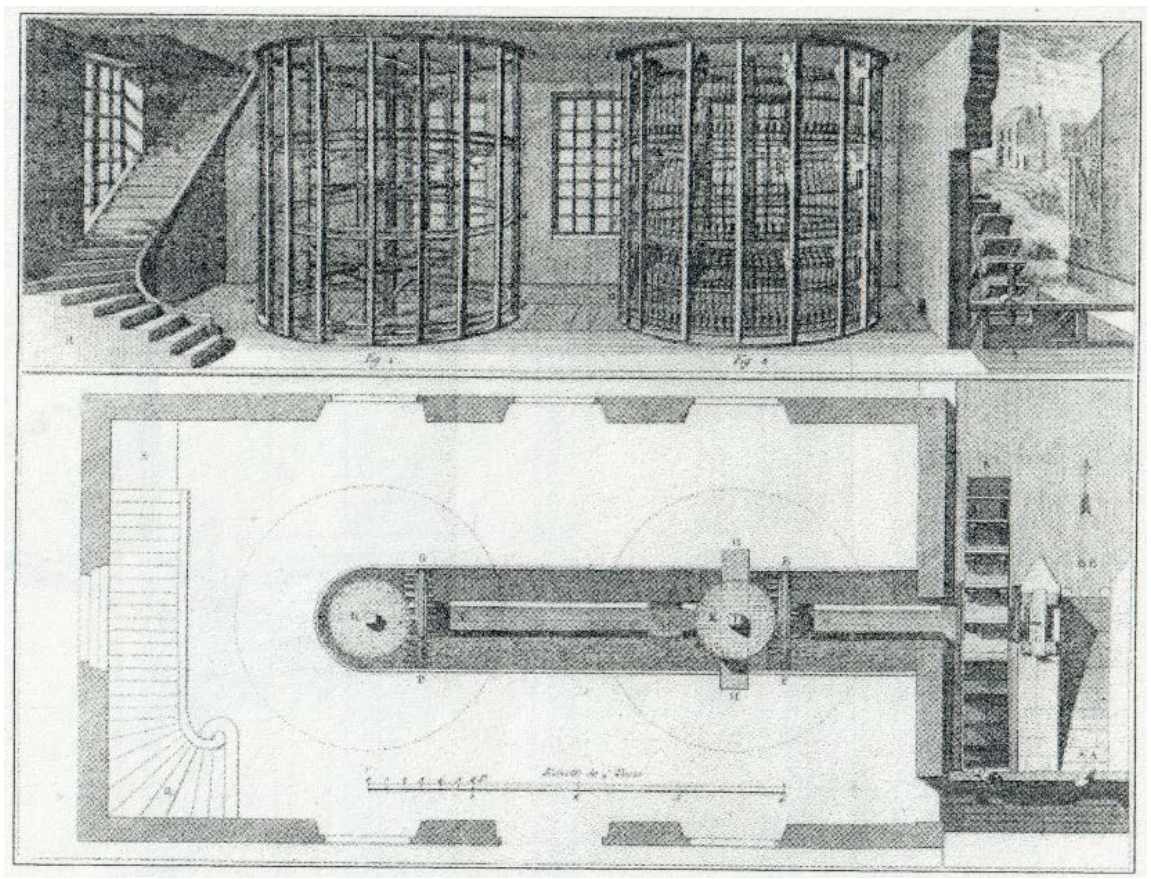

Figure 1. The internal and external part of the Bolognese mill, shown separately (Encyclopédie, t. XI, n. 2).

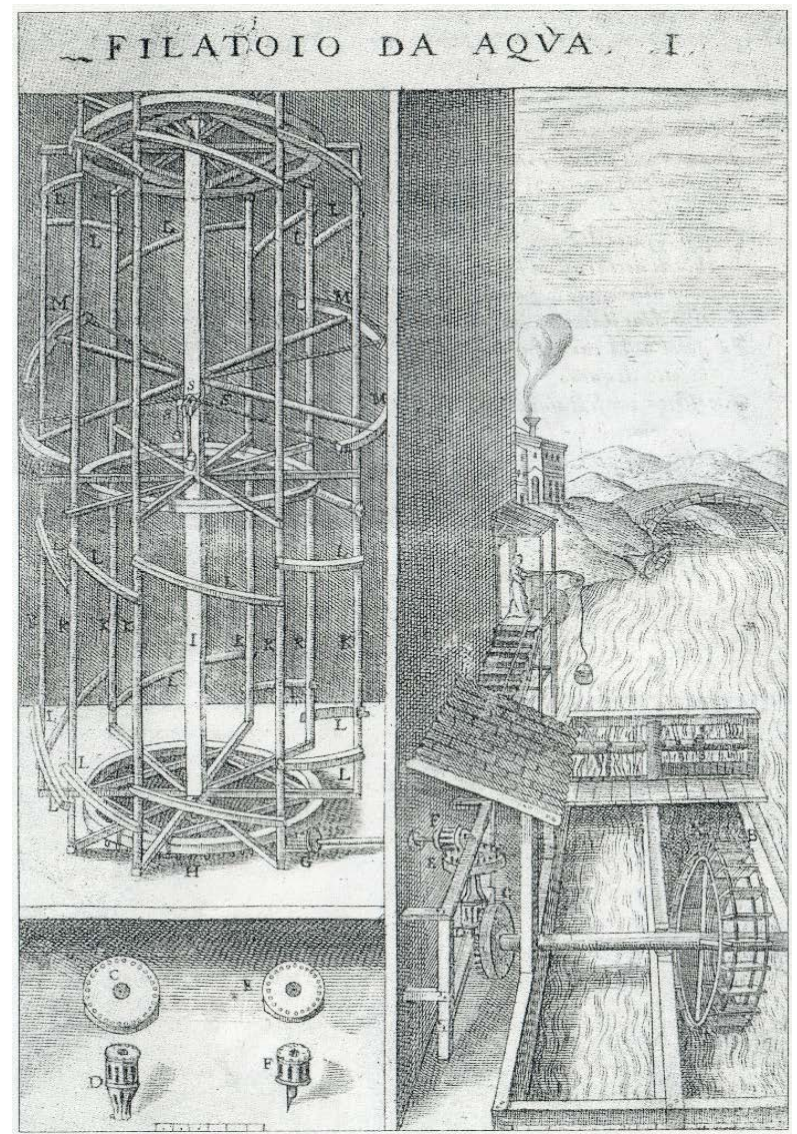

Figure 2. The internal part of the Bolognese mill, represented in detail (from: Zonca, 1607). 
The mill is put into rotation by the wheel $\mathrm{B}$, driven by the hydraulic power of the water of a river. A kinematic chain, made of the gears C, E, F, G brings the motion to the wheel $\mathrm{H}$, which puts into rotation the central shaft I of the ghirlanda. The central shaft has eight spokes fixed at different levels and resting on wooden circles. Many wooden poles (K), named colonnelli ("colonels"), are installed vertically and are fixed to the end of the spokes. Between each pair of consecutive colonnelli, an inclined rod is fixed: these rods (L) are called serpi ("snakes"). Four more spokes are radially fixed to the shaft I: at the end of each spoke, a rod M covered with leather is fixed, externally with respect to the colonnelli. These rods are called strofinacci ("dish clothes").

Referring to Figure 3, which shows the external structure of the mill, it can be noticed that the external part of the mill has different levels, called varchi ("openings"). In every level some reels (M) and spools (A) are placed. The reels and the spools are both put into rotation by the ghirlanda, in two different ingenious ways: the spools A are rotated by the strofinacci $\mathrm{M}$ that crawl on them, while the reels are put into rotation by the discontinuous movement of the spoked wheel F whose spokes, named bolzonelli, are moved by the serpi L, rotating together with the ghirlanda.

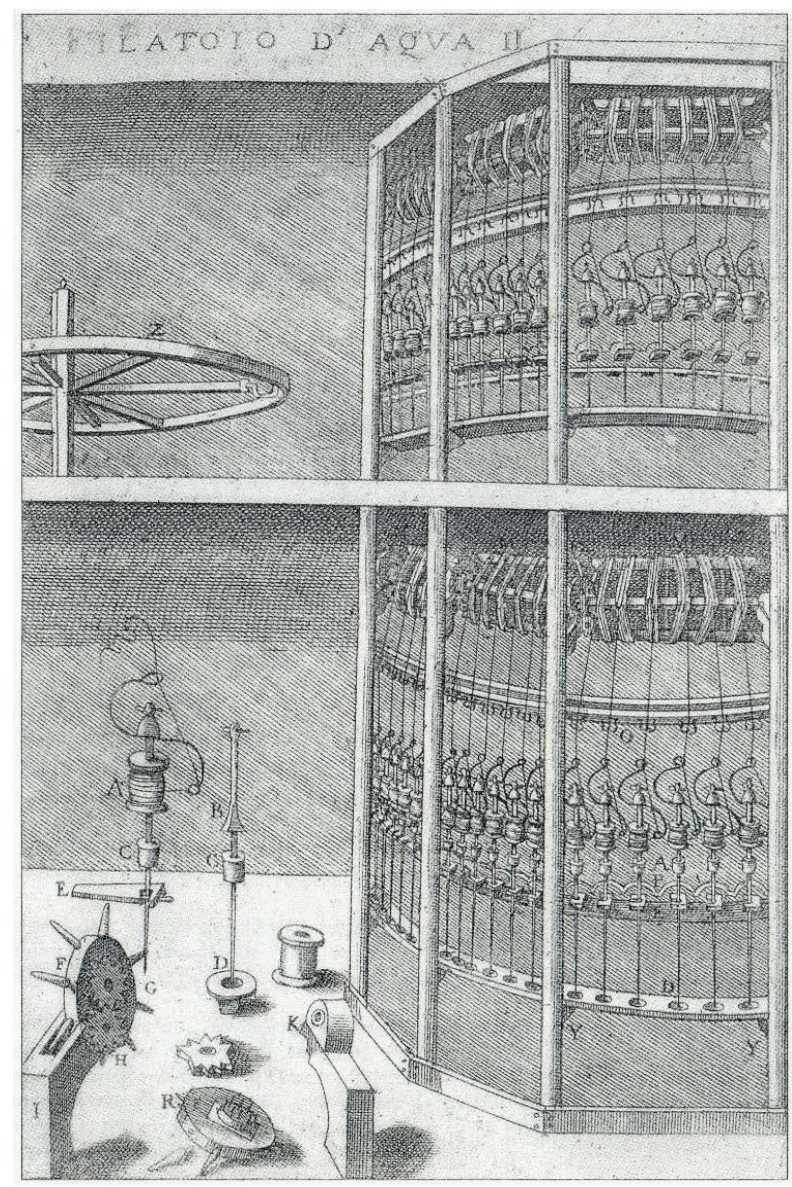

Figure 3. The external part of the Bolognese mill, represented in detail (from: Zonca, 1607). 
The twisting of the silk thread is also automatically implemented by the Bolognese mill, thanks to the rotation of the spool (on which the thread has been previously incannato, i.e. wrapped). The thread is forced to pass through two eyelets and to wrap on the reel.

The Museum of Industrial Heritage in Bologna (Italy) hosts an admirable reconstruction of the mulino da seta alla bolognese (see Figure 4). This reconstruction is very faithful and it is fully functional, being also able to move for the benefit of the visitors.

\subsection{The Milanese Silk Mill}

Figure 5 represents the drawing of a Milanese silk mill that can be found in the book by Martin (2009).

In the drawing, only the lower level of the mill is shown. The mill has 14 reels, 14 colonnelli and 6 spools between any pair of colonnelli. The silk threads are wrapped on the upper reel, after being twisted by the mechanism shown in the bottom-left part of the figure.

This mill is driven by manual and not by hydraulic force. Moreover, it has no mechanical winders and has reels instead of spools: thus, it belongs to the Milanese type.

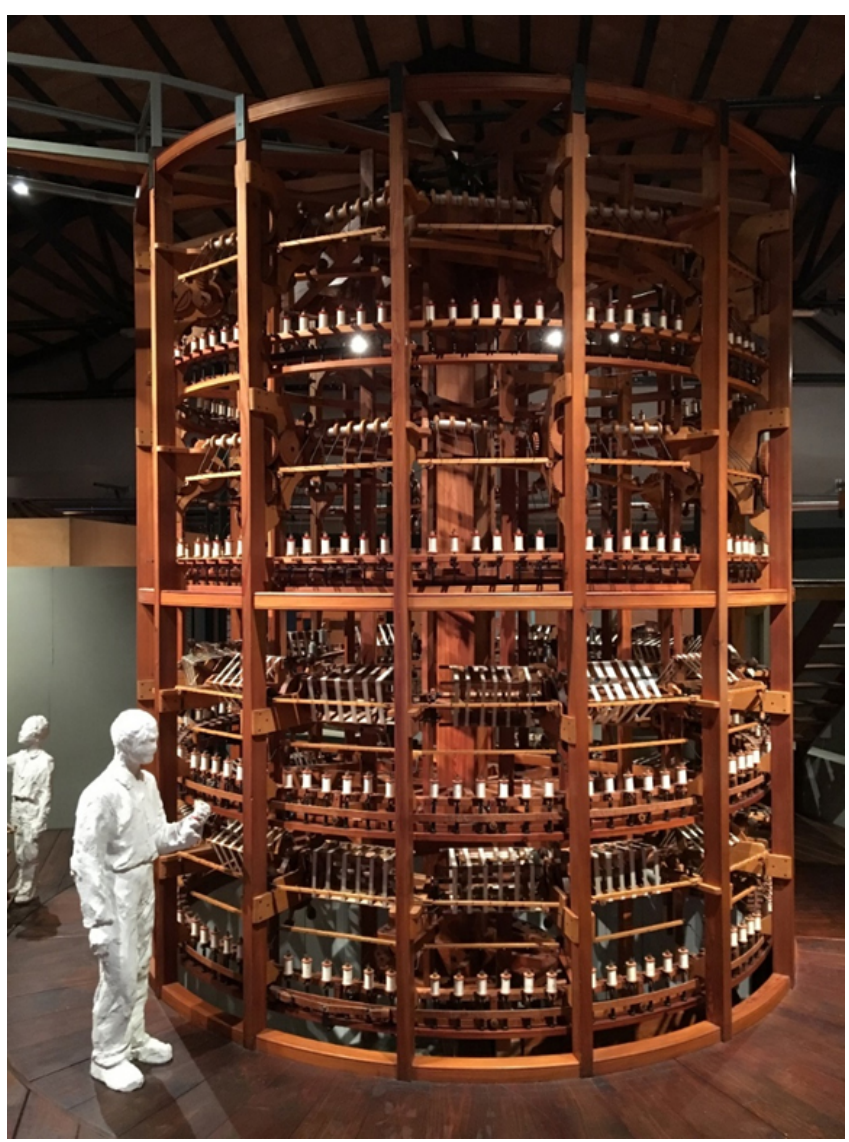

Figure 4. Reproduction of the Bolognese mill, located in the Museum of Industrial Heritage of Bologna (Italy). 


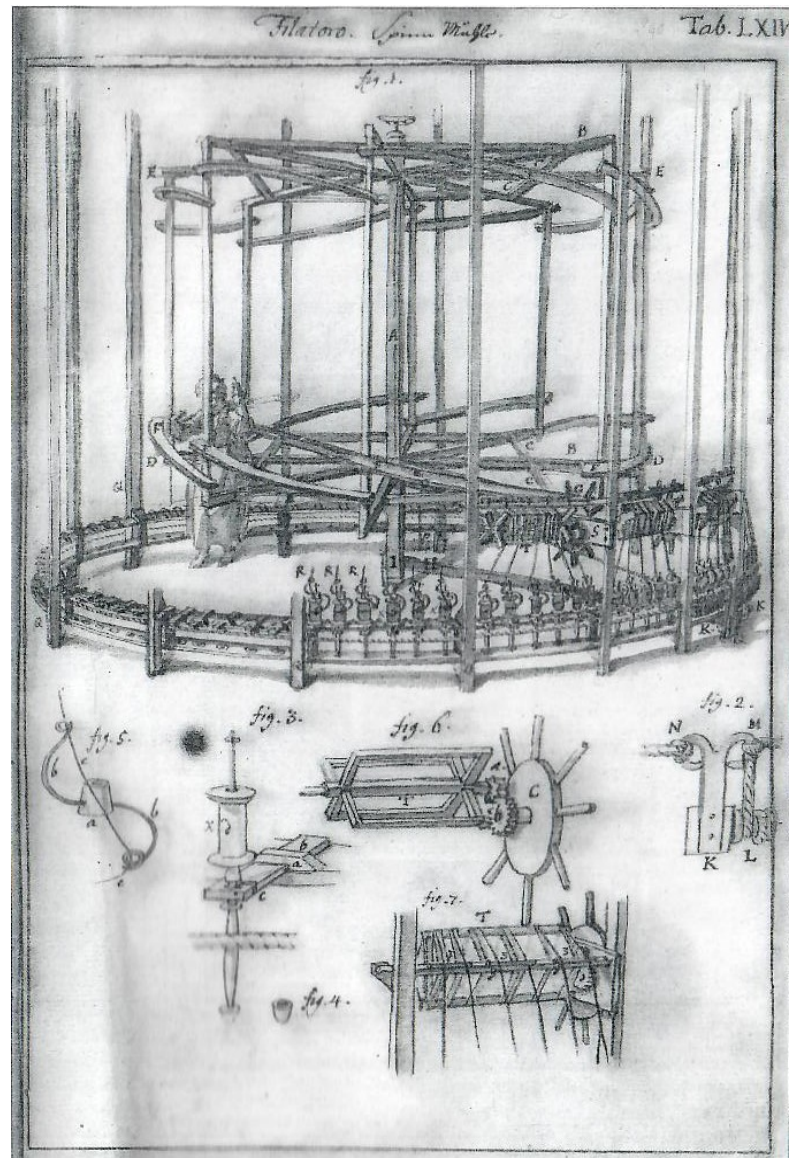

Figure 5. Milanese silk mill, in Martin (2009), t. 45.

\section{Conclusion}

Italian artisans maintained a leading position in the European silk sector during the early modern times and until the XVII century. Silk production flourished first in Lucca and then it spread across different parts of the Italian peninsula.

One key ingredient in the success story of the Italian silk sector was the mill technology that artisans used to spool, spin, couple and twist raw silk. Different types of mills were employed. Initially they were driven by human power; later on, also because of the increase in the size of mills, more powerful, hydraulically-driven, mills started being used.

Thanks to a pervasive network of underground water conduits, Bologna was the city where hydraulic silk mills diffused more intensively. In Bologna the mill technology was greatly improved and a fully mechanized mill was developed. The Bolognese silk mill (mulino da seta alla bolognese) was able to carry out different phases of silk processing with little intervention of the labor force. Remarkably, this automatized system was in place a couple of centuries before the cotton mills that characterized the industrial revolution and, for this reason, it is considered an early example of factory system (Berveglieri \& Poni, 2000).

In this paper, a brief historical overview of the silk sector in the early modern Italy has been presented. The role of silk mills in early modern Italy has been 
studied and their importance has been highlighted. A historical overview of the silk sector in Northern Italian cities, from the XII to the XVIII century, has been carried out. Particularly relevant, as mentioned before, was the case of Bologna, which has been studied and described in Section 2 of the paper.

Besides the historical study, a technical analysis of the mills using in silk factories has been carried out. Two basic types of mills, namely the mulino da seta alla bolognese (Bolognese silk mill) and the mulino da seta alla milanese $o$ alla genovese (Milanese or Genoese silk mill) have been analyzed in Section 3 of the paper, by making an accurate comparison of the two mills, with respect to their technical features and to their working principles. It turned out that the Bolognese silk mill was more advanced, from a technological point of view, with respect to the Milanese silk mill. This led to some important consequences, namely: the quality of the worked silk obtained from the Bolognese mill was higher than that produced by the Milanese mill, and the Bolognese mill allowed to automatize almost all the silk processing operations. As a result, the Bolognese silk manufacturers enjoyed a relevant advantage over their competitors in other cities of Northern Italy.

\section{Conflicts of Interest}

The authors declare no conflicts of interest regarding the publication of this paper.

\section{References}

Battistini, F. (2000). La Tessitura Serica Italiana Durante l'Età Moderna: Dimensioni, Specializzazione Produttiva, Mercati. In L. Molà, R.C. Mueller, \& C. Zanier (Eds.), La seta in Italia dal Medioevo al Seicento: dal baco al drappo (pp. 335-351). Venezia: Marsilio.

Berveglieri, R., \& Poni, C. (2000). L'innovazione nel settore serico: I brevetti industriali della Repubbblica di Venezia fra XVI e XVII secolo. In L. Molà, R.C. Mueller, \& C. Zanier (Eds.), La seta in Italia dal medioevo al seicento (pp. 477-508). Venezia: Marsilio.

Crippa, F. (2000). Dal Baco al Filo. In L. Molà, R.C. Mueller, \& C. Zanier (Eds.), La seta in Italia dal Medioevo al Seicento: Dal baco al drappo (pp. 3-33). Venezia: Marsilio.

Guenzi, A., \& Poni, C. (1989). Un "Network" plurisecolare: Acqua e industria a Bologna. Studi Storici, 30, 359-377.

Martin, G. C. (2009). Viaggio in Toscana 1725-1745. In O. Trumpy (Ed.), Modena.

Molà, L. (2000). The Silk Industry of Renaissance Venice. Baltimore: John Hopkins University Press.

Poni, C. (1972). Archéologie de la fabrique: La diffusion des moulins à soie "alla bolognese" dans les États vénitiens du XVI e au XVIII e siècle. Annales Esc, 27, 1475-1496. https://doi.org/10.3406/ahess.1972.422559

Poni, C. (2009). La seta in Italia: Una grande industria prima della rivoluzione industriale. Bologna: Il Mulino.

Zonca, V. (1607). Novo teatro di machine et edificii per uarie et sicure operationi: Co[n] le loro figure tagliate in rame e la dichiaratione, e dimostratione di ciascuna: Opera necesaria ad architetti, e a quelli, ch[e] di tale studio si dilettano. In P. Bertelli (Ed.), Padua. 